\title{
Travel fairs attendance with the reference to political instability: Belgrade Travel Fair
}

\author{
Darko Dimitrovski $^{1^{*}}$, Marijana Seočanac ${ }^{2}$ \\ ${ }^{1}$ University of Kragujevac, Faculty of Hotel Management and Tourism in Vrnjačka Banja \\ ${ }^{2}$ MSc student, University of Kragujevac, Faculty of Hotel Management and Tourism in \\ Vrnjačka Banja
}

\begin{abstract}
Travel fairs are someof the most important events in the field of business tourism. Due to their international character, they are exposed to numerous influences, among which the influence of political instability is nowadays especially pronounced. Figuring as one of the factors that affect all aspects of the tourism industry, the examination of the perception of political instability of various stakeholders in the tourism industry is gaining importance. Travel fairs are someof the best sources of the information about the impact of political instability on various providers in tourism. This paper investigates the connection between the exhibitors' perception of political instability and their unique characteristics. The survey was conducted through a questionnaire distributed to exhibitors during the 39th Belgrade Travel Fair. The data was analyzed through the SPSS platform, using frequency analysis, descriptive statistics and one way ANOVA. The results have shown significant differences in the exhibitors' perception of the political instability in relation to their level of education, the size of the company and the sources of information about travel fairs.
\end{abstract}

Keywords: trade fair, travel fair, political instability, Belgrade, Serbia

JEL classification: L83

\section{Učešće na sajmu turizma sa osvrtom na političku nestabilnost: Sajam turizma u Beogradu}

Sažetak: Sajmovi turizma predstavljaju jedan od najvažnijih događaja u oblasti poslovnog turizma. Zbog svog međunarodnog karaktera izloženi su brojnim uticajima među kojima je danas posebno izražen uticaj političke nestabilnosti. Kao jedan od faktora koji utiče na sve aspekte turističke industrije, istraživanje percepcije o političkoj nestabilnosti različitih stejkholdera u turističkoj industriji sve više dobija na značaju. Sajmovi turizma su jedan od najboljih izvora informacija o uticaju koji politička nestabilnost ima na različite pružaoce usluga u turizmu. Ovaj rad istražuje vezu između percepcije izlagača o političkoj nestabilnosti i njihovih jedinstvenih karakteristika. Istraživanje je sprovedeno putem upitnika koji je podeljen izlagačima tokom 39. Sajma turizma u Beogradu. Prikupljeni podaci su analizirani putem SPSS softverskog paketa, koristeći analizu frekvencija, deskriptivnu statistiku i analizu varijanse (ANOVA). Rezultati istraživanja su pokazali da postoje značajne razlike u percepciji izlagača o političkoj nestabilnosti u zavisnosti od njihovog nivoa obrazovanja, veličine kompanije i izvora informacija o sajmovima turizma.

Ključne reči: sajam, sajam turizma, politička nestabilnost, Beograd, Srbija JEL klasifikacija: L83

*darkomeg8@yahoo.com 


\section{Introduction}

Observed on a global scale, business tourism is one of the fastest growing sectors of the tourism industry. An increasing number of trips made for business reasons are recorded on an annual basis. The development of this kind of tourism brings prosperity to many tourist destinations. In order to be competitive on the market of business tourism, many destinations invest in building both infrastructure and superstructure, which provides positive effects for the destination itself as well as for the state.

Despite the development of modern technologies, the need for direct contact has existed and will always exist. Only in direct contact with people can a true impression of their competence, reliability and professionalism be created, and that is what will always encourage a certain kind of direct gathering. This is especially important in industries such as tourism, where the final service is intangible. As customers buy something intangible, it is necessary to provide some tangible elements of services. One of the ways in which this can be achieved is by attending a travel fair. Their role and importance, from the perspective of the sellers, is reflected in the possibility of promoting their offer to potential buyers and by establishing direct contact with them, create confidence in their services, and thus compensate for the lack which creates the intangibility of services they offer.

Travel Fairs bring together in one place exhibitors from various sectors of the tourism industry; hotels, restaurants, airlines, travel agencies, tour operators and tourism organizations that come from different countries to present their offer to potential tourists and to achieve cooperation with business partners. In Serbia and Southeast Europe, one of the largest tourist events is the Belgrade Travel Fair that has been held for almost 40 years. The Belgrade Travel Fair is one of the most important meeting points for various companies in tourism sector within the country or abroad. The fair offers an opportunity to all participants to gain new perspectives and promote latest trends in the international tourism.

Due to an increasing importance of trade fairs and travel fairs on a global scale, understanding exhibitors' profile and perception is seen as highly desirable. Along with other tourism events, travel fairs are affected by political instability, an aspect that cannot be diminished by both travel fair organizers and exhibitors'. The aim of the paper is to assess the relationship of the political instability regarding exhibitors' characteristics. An acknowledgement of the differences between exhibitors related to a political instability, has the capacity to provide the understanding of complex business strategies in relation to travel fair attendance.

\section{Literature review}

\subsection{Trade fairs}

Trade shows, trade fairs, expositions, the name may vary but the basic function of the activity represents a major marketing event (Black, 1986). Trade shows are an integral part of the marketing strategy for many products and services (Kellezi, 2014). They can be described as "events that bring together, in a single location, a group of suppliers, distributors and related services who set up physical exhibits of their products and services from a given industry or discipline" (Black, 1986, p. 369). The event is a dynamic and complicated process that covers everything from promotion, organization to sponsorship and support, and therefore, involves efforts from a wide range of players. Exhibition organizers, exhibitors and visitors have been identified as most important stakeholders (Bruhn \& Hadwich, 2005). For exhibitors, trade fairs are an effective marketing sales tool, which offer them the opportunity to establish their brand image, get knowledge about potential buyers' needs, 
observe competitors and make direct sales (Kaniewska - Seba et al., 2006). On the other hand, attending an exhibition allows the visitor to obtain information from many vendors in one place (Dwyer \& Tanner, 1999). Generally, trade shows can be used to stimulate domestic trade and promote exports when they are attended by foreign visitors (Davidson \& Cope, 2003).

Unlike today's view of fairs as marketing tools, in the past most firms participated as exhibitors just to follow competition, without setting any particular objectives or strategies to be pursued (Mottard, 2003; Pitta et al., 2006). However, businesses are now beginning to realize that there is more to exhibiting at a fair than simply setting up a stand and waiting for things to happen and that is one of the reasons why the trade show sector has been rapidly developing in the last few decades (Miller, 2003). Companies spend millions of dollars on trade show participation, identifying prospects, selling products, improving their public image, introducing new or modified products and servicing current customers (Gopalakrishna et al., 1995; Kerin \& Cron, 1987).

Specific conditions for the exchange of information and knowledge building are created during trade fairs because many actors meet at the same time so there is no physical distance between actors in the network (Sarmento et al., 2015; Siemieniako \& Gębarowski, 2017). Knowledge is the essential element of interest to both visitors and exhibitors (Zieliński \& Leszczynski, 2011), so trade fairs are seen as a perfect opportunity for knowledge diffusion (Zhong \& Luo, 2018). From the exhibitors' point of view, trade fairs are an excellent way to enter a new market or to build their image and maintain relations (Rosson \& Seringhaus, 1995). In sum, trade shows can provide the opportunity to affect multiple phases of the buying process in one location: they can create awareness of new prospects, reinforce existing customer relationships, improve the company image and allow sales on the spot (Moriarty \& Spekman, 1984).

\subsection{Travel fairs}

Satisfaction of customers is one of the main principles that a travel company business results depends on. Returning costumers as well as the established relationship of loyalty are indicators that the company is doing well on the tourist market. Knowledge of a potential tourist's needs and wishes and successful marketing strategies based on that determine sales and profit of a particular travel company (Djeri et al., 2007). In recent years, due to the effects of globalization and the subsequent increase in tourism activities, significant growth of travel fairs has been recorded. Their significance is particularly evident for travel and hospitality services providers due to their products' uniqueness, such as intangibility, perishability and variability (Yuksel \& Voola, 2010). Based on the following fact, travel fairs are frequently used by a range of organizations, including both public agencies and private enterprises to encourage tourists and travel retailers to buy tourism products, visit tourist destinations, increase destination or product awareness, reach potential audiences, and increase business (Pizam, 1990).

Within the travel fairs destinations and tourism, companies exhibit a tourism product at their stands which stands out by some specific features that affect overall exhibition activity. Complexity and hybrid structure of a tourism product cause that exhibitors' performances during trade shows have a form of micro-events which include, among other things, some contests, food and drink tasting, vocal and dance performances. All this is done in order to attract attention of visitors and engage all human senses so as to make visitors remember the exhibited tourism product with all unique qualities of the place (Gębarowski \& Wiażewicz, 2014). 


\subsection{Political instability}

One of the major determinants in travelers' decisions to visit a place is the perception of safety and security (Beirman, 2003). Tourists make their travel decisions based on perceptions rather than reality (Roehl \& Fesenmaier, 1992), so the risk perception influences tourists' behavior to avoid or cancel travel to a particular destination as Irvine and Anderson (2006) have stated. This leads to the fact that tourism can be characterized as an industry where both demand and supply can be sensitive to extreme events such as political instability (Richter \& Waugh, 1986; Ryan, 1993).

As a highly vulnerable industry and particularly sensitive to exogenous factors, which are able to distract and obstruct the sensitive equilibrium and balance under which the tourism industry is functioning, tourism is incredibly vulnerable to political instability (Seddighi et al., 2001). Political instability with high media coverage has the magnitude of impact greater then major natural disasters, such as hurricanes, earthquakes or floods, and can seriously affect the number of tourists and their expenditure (Santana, 2001). Characterized by a multifaceted and complex character, political instability has a multilevel and multidimensional impact in various countries worldwide (Gupta, 1990). The extent and magnitude of political instability are the determinant factors for the image of destinations in tourist generating countries and for the perceived stability and safety of a particular destination in the eyes of prospective holidaymakers (Seddighi et al., 2001). Political instability can be detrimental to tourism development both directly and indirectly. Directly, it can create an image of lawlessness and tourists may be concerned that they will be the target of different factions. Indirectly, economic growth and development which provide the foundation for tourism could be damaged by influence of political instability (Fletcher \& Morakabati, 2008).

Political instability has been identified in several studies (Ioannides \& Apostolopoulos 1999, Mansfeld, 1999, Seddighi et al., 2001) as a major risk for tourism development. There are numerous examples where the negative effects of political instability have led many tourist destinations to decline and totally disappear from the tourism map (Seddighi et al., 2001). Political instability can also cause the generalization effect by affecting neighboring countries that are not directly involved in any conflict (Fletcher \& Morakabati, 2008).

Changing the negative image created by political instability is not an easy and quick job. As one of the possibilities to reduce the negative effects of political instability for tourism destinations in particular could be travel fairs. Gathering tourist ambassadors from different countries or regions provides a possibility of influencing the perception of tourists especially in situations where a particular area is characterized by political or any other instability. Participation at a travel fair opens up an opportunity for foreign exhibitors to help improve the bad image that the media has created about the situation in their destination, as well as to try to convince tourists to visit a specific destination by their own presence and efforts. On the other hand, when it comes to the benefits of the travel fair for the country in which it is organized and which has until recently been marked as a politically unstable country, the organization of the travel fair and the participation of domestic exhibitors profiles the particular country as a safe destination for taking trips there.

\section{Methodology}

Belgrade Travel Fair is one of main travel fairs in this part of the Europe with the tradition of almost forty years. Depending on the year, it gathers around 800 exhibitors' from more than 40 countries from all over the world. This event holds UFI label providing global recognition 
and importance. Travel Fair in Belgrade is of utmost importance for neighbouring countries, and thus has a regional effect on tourism flows (Beogradski sajam turizma).

The survey was implemented during the $39^{\text {th }}$ Travel Fair during working days, since over the weekend number of visitors is increasingly higher and thus exhibitors are busier. Exhibitors in the main hall were approached by investigators and given fifteen minutes to respond to the questionnaire. Specifically, researchers have collected the main exhibitor data, and their opinion related to regional political instability based on a seven - point scale ( 1 - being not at all important; 7 - being extremely important). Questionnaire was initially evaluated within a small focus group in order to formulate understandable statements. In total, 205 questionnaires have been successfully completed and considered for further data analysis; unfortunately, some of the questionnaires have missing data.

Political instability as variable was formulated according to earlier studies dealing with this issue (Seddighi et al., 2001). However, statements which originate from this study were additionally adapted for the purposes of this study.

Data analysis was completed in the SPSS using following statistical analyses: frequency analysis; descriptive statistics and one way ANOVA. Frequency analysis was performed to identify the socio-demographic characteristics of exhibitors. Descriptive statistics was implemented in order to acquire mean values and standard deviations of political instability statements. Lastly, one way ANOVA was deployed to examine if there was difference in the perception of political instability between groups, based on demographic variables (age and education), type of the exhibitor, respondents' position in the firm, and other exhibitors' data (company size and information about travel fair).

\section{Results}

The demographic structure of the sample consists mostly of female respondents $(48.5 \%)$. The age group $(35-44)$ has the largest proportion of respondents $(37.6 \%)$, while most of the respondents (35.6\%) have obtained a bachelor's degree (Table 1).

Table 1: Sample demographic characteristics $(n=205)$

\begin{tabular}{|c|c|}
\hline Gender & Number of respondents (\%) \\
\hline Male & $92(44.9 \%)$ \\
\hline Female & $99(48.3 \%)$ \\
\hline Missing sample & $14(6.8 \%)$ \\
\hline Age & $12(5.9 \%)$ \\
\hline $18-24$ & $62(30.2 \%)$ \\
\hline $25-34$ & $77(37.6 \%)$ \\
\hline $35-44$ & $37(18.0 \%)$ \\
\hline $45-54$ & $11(5.4 \%)$ \\
\hline $55-64$ & $6(2.9 \%)$ \\
\hline Missing sample & $16(7.8 \%)$ \\
\hline Education & $64(31.2 \%)$ \\
\hline High school graduate & $73(35.6 \%)$ \\
\hline Associate degree & $43(21.0 \%)$ \\
\hline Bachelor's degree & $9(4.4 \%)$ \\
\hline Master's degree &
\end{tabular}

Source: Research by the authors 
Most significant source of information for exhibitors to attend a travel fair was the Internet (53.7\%). Respondents willing to engage in the survey were mostly employees $(52.7 \%)$, as owners were generally busy with networking activities. Structure of the sample was divided among hotel companies (47.3\%), DMO's (26.3\%) and travel agencies (22.4\%). Companies at a travel fair have approximate number of $5-20$ employees $(32.7 \%)$ (Table 2$)$.

Table 2: Exhibitors' information $(\mathrm{n}=205)$

\begin{tabular}{|c|c|}
\hline Information about travel fair & \\
\hline Internet & $110(53.7 \%)$ \\
\hline Advertisements in magazines or newspaper & $6(2.9 \%)$ \\
\hline Television & $15(7.3 \%)$ \\
\hline Word of mouth & $55(26.8 \%)$ \\
\hline Missing sample & $19(9.3 \%)$ \\
\hline Respondent position & $16(7.8 \%)$ \\
\hline Owner & $74(36.1 \%)$ \\
\hline Manager & $108(52.7 \%)$ \\
\hline Employer & $7(3.4 \%)$ \\
\hline Missing sample & $46(22.4 \%)$ \\
\hline Type of exhibitor & $54(26.3 \%)$ \\
\hline Travel agency / Tour operator & $97(47.3 \%)$ \\
\hline DMO & $8(3.9 \%)$ \\
\hline Hotel company & \\
\hline Missing sample & $36(17.6 \%)$ \\
\hline Company size & $67(32.7 \%)$ \\
\hline$<5$ & $45(22 \%)$ \\
\hline $5-20$ & $39(19 \%)$ \\
\hline $20-50$ & $18(8.8 \%)$ \\
\hline$>50$ &
\end{tabular}

Source: Research by the authors

Table 3 includes descriptive data regarding the exhibitors' perception of political instability. Political instability was evaluated through two statements encircling the unique nature of observed phenomena. Results obtained suggest that exhibitors generally gave high importance to political instability issues. The threat of the war in the wider region was considered as more important in comparison to a change in government, riots and political instability in neighbouring countries.

Table 3: Descriptive statistics of political instability ( $n=199$; Missing sample $n=6)$

\begin{tabular}{|c|c|c|}
\hline Statements & $\begin{array}{c}\text { Mean } \\
\text { values }\end{array}$ & $\begin{array}{c}\text { Standard } \\
\text { deviation }\end{array}$ \\
\hline $\begin{array}{c}\text { Change in government, riots and political instability in } \\
\text { neighbouring countries }\end{array}$ & 5.15 & 1.94 \\
\hline Threat of war in wider region & 5.39 & 1.95 \\
\hline
\end{tabular}

Source: Research by the authors

Table 4 presents the findings of one way ANOVA test related to demographic data. Observing age in the context of the political instability, it can be concluded that different age groups of respondents have heterogeneous attitudes. According to Scheffe Post hoc test, the statement "Change in government, riots and political instability in neighbouring countries" has been perceived in a significantly different manner between younger respondents $(25-$ $34 ; \mathrm{M}=4.51)$ and older respondents $(45-54 ; \mathrm{M}=5.71)$. As for the statement "Threat of 
war in wider region", a significant difference between younger respondents $(25-34 ; \mathrm{M}=$ 4.57), mid - age respondents ( $35-44 ; \mathrm{M}=5.81)$ and older respondents $(45-54 ; \mathrm{M}=5.76)$ has been identified. Focusing on different education categories, a statistically significant difference was found only for the first statement, distinguishing attitudes of respondents with a master's degree, $(\mathrm{M}=4.21)$, college degree $(\mathrm{M}=5.38)$ and bachelor degree $(\mathrm{M}=5.47)$ (Table 4).

Table 4: Results of ANOVA test for socio - demographic exhibitors data

\begin{tabular}{|c|c|c|c|c|}
\hline & \multicolumn{2}{|c|}{ Age } & \multicolumn{2}{|c|}{ Education } \\
\hline & $\mathrm{F}$ & $\mathrm{p}$ & $\mathrm{F}$ & $\mathrm{p}$ \\
\hline $\begin{array}{l}\text { Change in government, riots and political } \\
\text { instability in neighbouring countries }\end{array}$ & 2.854 & $0.025^{* *}$ & 4.368 & $0.005^{* *}$ \\
\hline Threat of war in wider region & 4.727 & $0.001^{* * * *}$ & 1.256 & $0.291^{\mathrm{ns}}$ \\
\hline
\end{tabular}

Source: Research by the authors

When the main exhibitors data was examined, any statistically significant differences regarding political instability statements were not recorded. Thus, it could be concluded that groups within respondent position and type of exhibitor have homogeneous attitudes on different aspects of political instability. Results of the one way ANOVA test are shown in Table 5.

Table 5: Results of ANOVA test for the main exhibitors' data

\begin{tabular}{|c|c|c|c|c|}
\hline & \multicolumn{2}{|c|}{$\begin{array}{l}\text { Respondent } \\
\text { position }\end{array}$} & \multicolumn{2}{|c|}{$\begin{array}{l}\text { Type of } \\
\text { exhibitor }\end{array}$} \\
\hline & $\mathrm{F}$ & $\mathrm{p}$ & $\mathrm{F}$ & $\mathrm{p}$ \\
\hline $\begin{array}{l}\text { Change in government, riots and political } \\
\text { instability in neighbouring countries }\end{array}$ & 1.418 & $0.245^{\mathrm{ns}}$ & 1.464 & $0.226^{\mathrm{ns}}$ \\
\hline Threat of war in wider region & 2.135 & $0.121^{\mathrm{ns}}$ & 0.422 & $0.737^{\mathrm{ns}}$ \\
\hline
\end{tabular}

Source: Research by the authors

Finally, Table 6 presents the findings of one way ANOVA test related to company size and information about travel fair. Result findings indicate that statistically significant differences have been noted for a company size and information about travel fair. Companies of different size have heterogeneous attitudes regarding political instability issues. Specifically according to Scheffe Post hoc test, the first statement has shown a different attitude by companies with a smaller number of employees $(5-20 ; \mathrm{M}=5.73)$ in comparison to companies with a larger number of employees ( $>50 ; \mathrm{M}=4.54$ ), while the second statement has emphasized a different perception of importance related to the threat of war for companies with $5-20$ employees $(\mathrm{M}=6.06)$ in comparison to companies with the smallest number of employees $(<5 ; \mathrm{M}=4.74)$ and companies with the largest number of employees $(>50 ; \mathrm{M}=5.00)$. The attitude towards political instability of respondents who use different sources of information about travel fair was also observed, indicating that there was a statistically significant difference for both political instability statements. The statement that covers the issue of the threat of war in the wider region is perceived differently byrespondents using Internet as main source for information about travel fair $(\mathrm{M}=5.05)$ and WOM (word of mouth) $(\mathrm{M}=$ 6.04) (Table 6). 
Table 6: Results of ANOVA test other exhibitors' data

\begin{tabular}{|c|c|c|c|c|}
\hline & \multicolumn{2}{|c|}{ Company size } & \multicolumn{2}{|c|}{$\begin{array}{c}\text { Information } \\
\text { about travel } \\
\text { fair }\end{array}$} \\
\hline & \multicolumn{1}{|c|}{$\mathrm{F}$} & $\mathrm{p}$ & $\mathrm{F}$ & $\mathrm{p}$ \\
\hline $\begin{array}{c}\text { Change in government, riots and political } \\
\text { instability in neighbouring countries }\end{array}$ & $\mathbf{3 . 6 7 1}$ & $\mathbf{0 . 0 1 3}{ }^{* *}$ & $\mathbf{2 . 5 9 9}$ & $\mathbf{0 . 0 5 4}$ \\
\hline Threat of war in wider region & $\mathbf{4 . 7 3 7}$ & $\mathbf{0 . 0 0 3}{ }^{* *}$ & $\mathbf{4 . 2 3 5}$ & $\mathbf{0 . 0 0 6}{ }^{* *}$ \\
\hline Notes: ${ }^{* *} \mathrm{p}<0.05{ }^{*} \mathrm{p}<0.1{ }^{\mathrm{ns}}$ non - significant
\end{tabular}

Source: Research by the authors

\section{Discussion and conclusion}

As political instability is becoming the global concern, this issue has become one of the main factors in the decision making process related to any sector in tourism, with special importance for travel fair attendance and organization. Several studies have already proven the importance of political instability for destination (Sönmez, 1998; Causevic \& Lynch, 2013; Saha \& Yap, 2013), while its importance was neglected regarding business tourism, and more specifically exhibitions within this sector.

One of the important conclusions of the conducted study is the fact that political instability importance has been highly valued by company representatives attending travel fair. More precisely, respondents give higher importance to the perception of the threat of war in the wider region, due to unstable political situation with highly visible daily hostilities between countries within observed region. This is somehow in the line with earlier study done by Hughes (2008), who suggested that political instability is still an everyday subject when it comes to the countries of former Yugoslavia, along with daily political conflicts in the surrounding countries such as Greece and Turkey. Travel fairs could be used as a tool to cope with unfortunate reality and enhance interregional collaboration using transformative power of tourism to bring peace (Farmaki, 2017) and stability in regional economic market.

It was interesting to observe the phenomenon of political issues in the context of demographic and other exhibitors' data, in order to determine the potential differences between groups in researched categories. On the level of demographic characteristics of the representatives of the companies exhibiting at the travel fair, the representatives of different age and level of education have shown a different perception of political instability. Specifically, concern about government change, riots and political instability in neighbouring countries was more expressed by older respondents. Older generations are more aware of the consequences of political instability in the wider region and therefore they perceive it as more important for tourism development. They are aware that exhibiting at travel fair provides them with an opportunity to bring more optimistic message to tourist, thus using this attendance as a crisis management instrument (Beljic, 2017). The difference was noticed also at the level of education, underlining that more highly educated representatives of tourism companies give lower importance to political instability then the representatives with a lower level of education. Exhibitors with higher education, having a wider picture in mind, are already aware of the ongoing global political instability, so they do not take it so seriously on the regional level, while exhibitors with lower level of education are more influenced by constant media coverage of political turmoil increasing its importance for future business activities.

By observing exhibitors data including the respondent's position and the type of exhibitor, findings suggest that there are homogeneous attitudes on different aspects of political instability within groups. However, the aspect of political instability is perceived differently 
by exhibitors from smaller and larger companies and regarding source of information of travel fair attendance. Smaller companies as exhibitors at travel fairs perceive political instability as more important than companies with a higher number of employees. These companies are usually very sensitive to any changes in both economic and political environment in the region so their higher awareness of political instability is expected. On other hand, larger companies have a continuity in their business activities and therefore they are more resistant to political risks. However, a business strategy cannot ignore the consequence that political instability generates huge problems to firms, especially to the companies in the industry such as tourism, which is more open and vulnerable than other industries. The threat of political instability needs to be calculated in marketing strategies, for both small and large companies, using travel fairs to promote the picture of a secure and safe destination.

Lastly, attitude towards political instability has been significantly perceived by exhibitors which have used Internet as the main source for information about the travel fair in comparison to the word of mouth. This is a reasonable conclusion as companies that use Internet are also taking into account the media coverage about region related to the political instability, so they take political instability issues as more important. On the other hand, exhibitors that have been choosing a travel fair based on the word of mouth already have a direct insight in the political situation in the region providing valuable material for the final decision.

Limitation of the study is solely exhibitors' perspective, as the travel fair as the consumer trade fair provides opportunity for deeper insight in visitors' (tourists') perception related to the political instability. Future research could also include visitors' perception, or provide a cluster analysis of exhibitors based on their perception of political instability and provide insight in its relation to satisfaction, word of mouth and revisit intention.

\section{References}

1. Beirman, D. (2003). United States: September 11, 2001 terrorist attack. The impact on American and global tourism. In D. Beirman (Ed.), Restoring tourism destinations in crisis: A strategic marketing approach (pp. 43-68). Oxon: CABI Publishing.

2. Beljić, B. (2017). Krizni menadžment turističke destinacije [Crisis management of tourist destination]. Menadžment u hotelijerstvu i turizmu, 5(1), 36-43.

3. Beogradski sajam turizma [Belgrade Tourism Fair]. (2018). Retrieved March 15, 2018 from http://beogradskisajamturizma.rs/

4. Black, R. (1986). The Trade Show Industry: Management and Marketing Career Opportunities. East Orleans, MA: Trade Show Bureau.

5. Bruhn, M. \& Hadwich, K. (2005). Managing the service quality of trade fairs. In M. Kirchgeorg (Ed.), Trade show management: Planning, implementing and controlling of trade shows, conventions and events (pp. 787 - 821). Gabler Verlag.

6. Causevic, S. \& Lynch, P. (2013). Political (in)stability and its influence on tourism development. Tourism Management, 34, 145-157.

https://doi.org/10.1016/j.tourman.2012.04.006

7. Davidson, R. \& Cope, B. (2003). Business Travel - Conferences, Incentive Travel, Exhibitions, Corporate Hospitality and Corporate Travel, Pearson Education.

8. Djeri, L., Plavša, J. \& Čerović, S. (2007). Analysis of Potential Tourist`s Behaviour in the Process of Deciding Upon a Tourist Destination Based on a Survey Conducted in Bačka Region. Geographica Pannonica, 11, 70-76.

https://doi.org/10.5937/GeoPan0711070D

9. Dwyer, R. \& Tanner, J. F., Jr. (1999). Business marketing: Connecting strategy, relationship, and learning. San Francisco: Irwin McGraw-Hill. 
10. Farmaki, A. (2017). The tourism and peace nexus. Tourism Management, 59, 528540. http://dx.doi.org/10.1016/j.tourman.2016.09.012

11. Fletcher, J. \& Morakabati, Y. (2008). Tourism Activity, Terrorism and Political Instability within the Commonwealth: The cases of Fiji and Kenya. International Journal of Tourism Research, 10, 537-556. https://doi.org/10.1002/jtr.699

12. Gębarowski, M. \& Wiażewicz, J. (2014). Contemporary trade shows as a place of knowledge sharing about tourism products. Human Capital Without Borders: Knowledge and Learning for Quality of Life: Proceedings of the Management, Knowledge and Learning International Conference 2014, 25-27 June 2014, Portorož, Slovenia.

13. Gopalakrishna, S., Lilien, G. L., Williams, J. D. \& Sequeira, J. K. (1995). Do trade shows pay off? Journal of Marketing, 59(3), 75 - 83. https://doi.org/10.2307/1252121

14. Gupta, D. (1990). The economics of political instability: The effect of political instability on economic growth. New York: Praeger.

15. Hughes, H. L. (2008). Visitor and non-visitor destination images: The influence of political instability in South-Eastern Europe. Turizam: međunarodni znanstvenostručni časopis, 56(1), 59-74.

16. Ioannides, D. \& Apostolopoulos, Y. (1999). Political Instability, War and Tourism in Cyprus: Effects, Management and Prospects for Recovery. Journal of Travel Research, 38(1): 51-56. https://doi.org/10.1177/004728759903800111

17. Irvine, W. \& Anderson, A. R. (2006). The effect of disaster on peripheral tourism places and the disaffection of prospective visitors. In Y. Mansfeld, \& A. Pizam (Eds.), Tourism, security \& safety: From theory to practice (pp. 169-186). Oxford: Butterworth-Heinemann.

18. Kaniewska-Sẹba, A., Kuca, A., Leszczyń ski, G., Mruk, H., Mruk, J. \& Zalewski, B. (2006). In H. Mruk, \& A. Kuca (Eds.), Trade fair marketing: Exhibitor's manual. Poznań : Polish Trade Fair Corporation.

19. Kellezi, J. (2014). Trade shows: A strategic marketing tool for global competition. Procedia Economics and Finance, 9, 466-471. https://doi.org/10.1016/S2212$\underline{5671(14) 00048-3}$

20. Kerin, R. A. \& Cron, W. L. (1987). Assessing trade show functions and performance: an exploratory study. Journal of Marketing, 51(3), 87-94.

https://doi.org/10.2307/1251649

21. Mansfeld, Y. (1999). Cycles of War, Terror and Peace: Determinants and Management of Crisis and Recovery of the Israeli Tourism Industry. Journal of Travel Research, 38(1): 30-36. https://doi.org/10.1177/004728759903800107

22. Miller, S. (2003). Saque el maximo provecho de las ferias [Make the most of the fairs]. Barcelona: Ediciones Urano.

23. Moriarty, R. T. Jr. \& Spekman, R. E. (1984), An empirical investigation of the information sources used during the industrial buying process, Journal of Marketing Research, 21, 137-47. https://doi.org/10.2307/3151696

24. Mottard, E. (2003). Cuanto es de rentable participar en una feria? [How much is profitable to participate in a fair?] Marketing y Ventas, 182: 44-47.

25. Pitta, D. A., Weisgal, M. \& Lynagh, P. (2006). Integrating exhibiting marketing into integrated marketing communications. The Journal of Consumer Marketing, 23(3): 156-166. https://doi.org/10.1108/07363760610663312

26. Pizam, A. (1990). Evaluating the effectiveness of trade shows and other tourism salespromotion techniques. Journal of Travel Research, 29(1), 3-8. https://doi.org/10.1177/004728759002900102

27. Richter, L. \& Waugh, W. (1986) Tourism Politics and Political Science: A Case of Not So Benign Neglect. Annals of Tourism Research, 10, 313-315. https://doi.org/10.1016/0160-7383(83)90060-9 
28. Roehl, W. S. \& Fesenmaier, D. R. (1992). Risk perceptions and pleasure travel: an exploratory analysis. Journal of Travel Research, 2(4), 17-26.

https://doi.org/10.1177/004728759203000403

29. Rosson, P. J. \& Serinhaus, F. H. R. (1995). Visitor and exhibitor interaction at industrial trade fairs. Journal of Business Research, 32, 81-90. https://doi.org/10.1016/0148-2963(94)00012-4

30. Ryan, C. (1993). Crime, Violence, Terrorism and Tourism. Tourism Management, 14, 7-10. https://doi.org/10.1016/0261-5177(93)90018-G

31. Saha, S. \& Yap, G. (2013). The moderation effects of political instability and terrorism on tourism development: a cross-country panel analysis. Journal of Travel Research, 53(4), 509-521. https://doi.org/10.1177/0047287513496472

32. Santana, G. (2001). Globalisation, safety and national security. In Wahab S, \& Cooper C (Eds). Tourism in the Age of Globalisation (213-241), London: Routledge.

33. Sarmento, M., Farhangmehr, M., \& Simões, C. (2015). A relationship marketing perspective to trade fairs: insights from participants. Journal of Business \& Industrial Marketing, 30(5): 584-593. https://doi.org/10.1108/JBIM-01-2013-0024

34. Seddighi, H. R., Nuttall, M. W. \& Theocharous, A. L. (2001). Does cultural background of tourists influence the destination choice? An empirical study with special reference to political instability. Tourism Management, 22(2), 181-191. https://doi.org/10.1016/S0261-5177(00)00046-7

35. Siemieniako, D. \& Gębarowski, M. (2017). B2B trade fairs and promise management as a relationship marketing concept. Journal of Customer Behaviour, 16(3), 237-261. https://doi.org/10.1362/147539217X15071081721116

36. Sönmez, S. F. (1998). Tourism, terrorism, and political instability. Annals of Tourism Research, 25(2), 416-456. https://doi.org/10.1016/S0160-7383(97)00093-5

37. Yuksel, U. \& Voola, R. (2010). Travel trade shows: exploratory study of exhibitors' perception. Journal of Business \& Industrial Marketing, 25(4), 293-300. https://doi.org/10.1108/08858621011038252

38. Zhong, D., \& Luo, Q. (2018). Knowledge diffusion at business events: The mechanism. International Journal of Hospitality Management, 71, 111-119. https://doi.org/10.1016/j.ijhm.2017.12.003

39. Zieliński, M. \& Leszczynski, G. (2011). Trade fairs as source of knowledge - the role of trade fairs organizer. In The impact of globalization on networks and relationships dynamics-IMP-conference. Glasgow, Scotland. 